\title{
ATTITUDE OF STUDENT TEACHERS TOWARDS TEACHING PROFESSION
}

\author{
Asst. Professor Anupama BHARGAVA \\ St. Xavier`s College, Ranchi, Jharkhand, INDIA
}

Former Principal, Dr. MK PATHY

Dr. P. M. Institute of Advanced Study in Education,

Sambalpur, Orissa, INDIA

\begin{abstract}
Teaching being a dynamic activity requires a favourable attitude and certain specific competencies from its practitioners. Teachers' proficiency depends on the attitude she possesses for the profession. The positive attitude helps teacher to develop a conductive learner friendly environment in the classroom. This also casts a fruitful effect on learning of the students. Attitude being a social construct is influenced by many factors like gender social strata ,age, stream of education and previous experience of the job .what bearing the gender and stream of education has on the attitude of student teachers towards teaching profession to throw light on this a study was conducted using a readymade tool. Study of different categories like Non-tribal male and female science stream, nontribal male and female social science stream, Tribal male and female science stream, Tribal male and female social science stream was undertaken. In a sample of hundred students ninety six students responded. The mean scores were considered and ' $t^{\prime}$ value was calculated to find the difference in the attitude of different categories towards teaching profession.
\end{abstract}

Keywords: Attitude, Behaviour, teaching proficiency, student teachers.

\section{INTRODUCTION}

The teacher's roles and responsibilities have found extension outside the classroom. The implementation of educational policies, transaction of curricula and spreading awareness are the main areas which keep teacher in the forefront. Changing times have added new dimension to this profession, which requires specified competencies and right attitude. Behaviour, attitude and interest of teacher help in shaping the personality of the student. Attitude is a tendency to react in a particular manner towards the stimuli (Anastasi, 1957).

It is a dynamic entity which is subject to change. It is a deciding factor of the teacher's performance. Attitude is defined as a state of readiness shaped through the experience and influences the response of individual towards the stimuli. It is precursor of the behaviour and varies from favourable to unfavourable through neutral. Attitude is made up of three components affective, behavioural and cognitive hence acts as a yardstick of the individual behaviour (Feldman, 1985). Factors which bear influence on the attitude of the teacher are the domestic environment, family background, socioeconomic background, beliefs and educational institutes etc. 
School status, school infrastructure, safety conditions in the school, social and professional status all these factors are vital in casting impression on the teachers attitude(Barros \& Ela 2008).

Another factor which casts influence on the attitude is the experience.This holds true for teaching profession also. Teaching experience of the teacher contributes significantly in forming attitude (Suja, 2007). The teacher's attitude towards the subject and student is significant in creating desire to learn in the students. Gender and type of training are the paramount factors influencing the attitude of the teacher (Oral, 2004; Bozdogen et al, 2007). It is found that female teachers have positive attitud towards teaching profession (Capa \& cil; 2007). Inadequate financial remuneration and delay in payment of salaries are the causes of teacher's having low attitude towards teaching profession(Osunde \& izevbigie,2006). These negative factors when minimized can encourage teachers to be more conscious and responsible towards their duties. Initial teacher training helps in shaping the attitude of student teachers towards teaching profession.

Development of positive attitude towards profession helps in developing creative thinking and motivating students (Celikoz \& Cetin; 2004). The different learning environment, instructional materials and strategies adopted in initial teacher training programme are also responsible for difference in attitude of student teachers towards teaching profession (Mckeachie, 1994; Mordi; 1991; Schibeci \& Riley,1986). The type of attitude possessed by the teacher influence the quality of the work accomplished and teaching. Attitude of the teacher has the imprint of competencies that she possesses.

\section{THE BACKGROUND}

A number of studies have been conducted to assess the influence of attitude towards teaching profession on the teacher's performance inside and outside the classroom and the factors which have bearing upon it.

Devi (2005) found that success in teaching field depends upon two prime factorsattitude towards profession and job satisfaction. Suja (2007) also confirmed similar findings. According to him, attitude towards profession, interest in profession and teaching experience influence job commitment of the teacher. Mathai (1992) in his study emphasised that attitude towards profession and success in teaching are correlated to each other. In another study, Cornelius (2000) revealed that intelligence, attitude towards teaching and academic achievement of teacher trainee cast impression on their competence. Gynanduru and Kumar (2007) established that over achievers and average achievers possess more favourable attitude towards teaching in comparison to under achievers. Pushpam (2003) confirmed positive relationship between women teachers' attitude towards teaching and job environment.

Studies on attitude reveal that teacher's efficiency and classroom performance are based on her attitude towards profession up to a large extent. Most of the studies have highlighted the gender of teacher, academic achievement and job satisfaction as the factors influencing attitude towards profession. The present study is an effort to find out the bearing of factors like gender (Male/Female), Category (Tribal/Non-tribal) and stream of education (Science/Social science) on the attitude of student teachers of Jharkhand. 
> To determine the attitude of male and female (non tribal) science stream student teachers towards teaching profession.

$>$ To find out the attitude of male and female (nontribal) social science stream student teachers towards teaching profession.

$>$ To determine the attitude of male and female (Tribal) science stream student teachers towards teaching profession.

$>$ To determine the attitude of male and female (Tribal) social science stream student teachers towards teaching profession.

$>$ To bring in light the difference in attitude of non tribal and tribal students with respect to their stream of education.

\section{Hypotheses}

$>$ There is no difference in the attitude of male and female (non tribal) science stream student teachers towards teaching profession.

$>$ There is no difference in the attitude of male and female (nontribal) social science stream student teachers towards teaching profession.

$>$ There is no difference in the attitude of male and female (Tribal) science stream student teachers towards teaching profession.

$>$ There is no difference in the attitude of male and female (Tribal) social science stream student teachers towards teaching profession.

$>$ There is no difference in attitude of tribal and nontribal (female) student teachers of science stream towards teaching profession.

$>$ There is no difference in attitude of tribal and nontribal (male) student teachers of science stream towards teaching profession.

$>$ There is no difference in attitude of tribal and nontribal (male) student teachers of science stream towards teaching profession.

$>$ There is no difference in attitude of tribal and nontribal (female) student teachers of social science stream towards teaching profession.

$>$ There is no difference in attitude of tribal and nontribal (male) student teachers of social science stream towards teaching profession.

\section{METHODOLOGY}

To assess the attitude of student teachers towards teaching profession the teacher attitude inventory developed by Dr. S. P. Ahluwalia has been used as a tool.

\section{Population}

All student teachers of B.Ed. programmes run in Ranchi.

\section{Sample Size}

For the present study the sample size remains restricted to one hundred. Four students were absent, so only ninety six students responded. All student teachers belonged to the same college purposive stratified sampling is done by the researcher. Sample categorized for the study is as Non tribal (male \& female) science stream, Nontribal (male and female) social science stream, Tribal (male \& female) science stream, Tribal (male \& female) social science stream, Female (tribal\& nontribal)science stream, male (tribal \& nontribal) science stream, Female (tribal\& nontribal) social science stream, Male (tribal \& nontribal) social science stream. 
Tool Used

The teacher attitude inventory is a ninety item likert instrument consisting of six subscales. Each subscale has fifteen statements that pertain to a particular aspect of prospective and practicing teacher's professional attitudes.

The six aspects dealt with in the inventory are attitude towards teaching profession, class room teaching, child centred practices, educational process, pupils and teachers. Out of ninety items fifty six are in positive declarative form and thirty four of them are in negative form.

Forty three items are meant to assess attitude in favourable direction and forty six in unfavourable direction. Likert continuum strongly, agree, undecided, disagree and strongly disagree has been provided for each item. The subjects responded by putting tick mark in the chosen alternative against the serial number of the attitude statement in the answer sheet.

Though no time limit was assigned for recording responses on the answering Performa, yet student teachers were asked to complete it as soon as possible.

Once the exercise was over the different categories were sorted out like male/female, tribal/non-tribal, and science/arts.

\section{Scoring}

Each item alternative has been assigned a score ranging from 4 (strongly agree) to 0 (strongly disagree) for favourable items. In case of unfavourable items the scoring range is reversed i.e. from 0 (strongly agree) to 4 (strongly disagree). The attitude score of a subject is the sum total of item scores of all the six sub scales. The theoretical range of scores is from 0 to $\mathbf{3 6 0}$. Higher score indicate more favourable attitude towards teaching profession.

\section{Data Analysis}

Table: 1

Aggregate score of Non-Tribal student teachers (Science stream)

\begin{tabular}{|l|c|c|}
\hline & Female & Male \\
\hline Mean & 263.00 & 272.57 \\
\hline Variance & 203.143 & 380.53 \\
\hline SD & 14.64 & 21.07 \\
\hline Observations & 21 & 7 \\
\hline t Stat & \multicolumn{2}{|l}{} \\
\hline NS: Non significant & \multicolumn{2}{|l}{} \\
\hline
\end{tabular}

Analysis: The Set 1 shows the scores of non tribal (science group). In this group twenty one females and seven males are present. Attitude of both the groups towards teaching profession was analyzed using $t$ test to study significant difference between both the groups. The results show no significant difference between both the groups. 
Table: 2

Aggregate score of Non-Tribal student teachers (Social Science stream)

\begin{tabular}{|l|c|c|}
\hline & & Male \\
\hline Mean & 278.74 & 270 \\
\hline Variance & 131.878 & 347 \\
\hline SD & 11.80 & 20.41 \\
\hline Observations & 19 & 6 \\
\hline t Stat & \multicolumn{2}{|c|}{} \\
\hline NS; Non Significant & \multicolumn{2}{|c|}{} \\
\hline
\end{tabular}

Analysis: $\mathbf{t}$ score is non-significant at $\mathbf{5 \%}$ level. It shows that no difference in attitude towards teaching profession is present between Non-tribal Male \& Female in Social Science group.

Table: 3

Tribal student teachers (Science stream)

\begin{tabular}{|l|c|c|}
\hline & Female & Male \\
\hline Mean & 276.50 & 262.667 \\
\hline Variance & 133.25 & 17.556 \\
\hline SD & 12.65 & 5.13 \\
\hline Observations & 6 & 3 \\
\hline t Stat & $2.61145 *$ & \\
\hline *significant at 5\% level & \multicolumn{2}{|}{} \\
\hline
\end{tabular}

Analysis: There is significant difference in attitude towards teaching profession between Male \& Female students in Science group.

Table: 4

Aggregate score of Tribal student teachers (Social Science stream)

\begin{tabular}{|c|c|c|}
\hline & Female & Male \\
\hline Mean & 277.862 & 244.75 \\
\hline Variance & 374.188 & 607.688 \\
\hline SD & 19.49 & 26.35 \\
\hline Observations & 30 & 8 \\
\hline t Stat & \multicolumn{2}{|c|}{$3.51256 * *$} \\
\hline$* *$ significant at 1\% level & \multicolumn{2}{|c|}{} \\
\hline
\end{tabular}

Analysis: It is evident that difference in attitude towards teaching profession is present amongst tribal Male \& female students of Social Science stream. 
Table: 5

Science stream Student teachers (Female)

\begin{tabular}{|l|c|c|}
\hline & Tribal & Non-Tribal \\
\hline Mean & 276.50 & 263.00 \\
\hline Variance & 133.25 & 203.43 \\
\hline SD & 12.65 & 14.60 \\
\hline Observations & 6 & 21 \\
\hline t Stat & $2.3909 *$ & \\
\hline$*$ significant at 5\% level & & \\
\hline
\end{tabular}

Analysis: $\mathbf{t}$ score is significant at $\mathbf{5 \%}$ level which implies that difference in attitude towards teaching profession is present tribal female \& Non- tribal female student teachers of Science stream

Table: 6

Science stream Student teachers (Male)

\begin{tabular}{|l|c|c|}
\hline & Tribal & Non-Tribal \\
\hline Mean & 262.67 & 272.571 \\
\hline Variance & 17.556 & 380.531 \\
\hline SD & 5.132 & 21.07 \\
\hline Observations & 3 & 7 \\
\hline t Stat & & $-1.2764(\mathrm{NS})$ \\
\hline NS: Non significant & \multicolumn{2}{|}{} \\
\hline
\end{tabular}

Analysis: $t$ score shows that there is no significant difference between the tribal \& nontribal male students' attitude towards teaching profession.

Table: 7

Social Science stream Student teachers (Female)

\begin{tabular}{|l|c|c|}
\hline & Tribal & Non-Tribal \\
\hline Mean & 277.724 & 278.737 \\
\hline Variance & 377.165 & 131.878 \\
\hline SD & 19.26 & 11.80 \\
\hline Observations & 30 & 19 \\
\hline t Stat & & \\
\hline NS: Non significant & \multicolumn{2}{|c|}{} \\
\hline
\end{tabular}

Analysis: There is no significant difference in the attitude of Female tribal \& nontribal (social science) student teachers towards teaching profession. 
Table: 8

Social Science stream Student teachers (Male)

\begin{tabular}{|c|c|c|}
\hline & Tribal & Non-Tribal \\
\hline Mean & 244.75 & 270.00 \\
\hline Variance & 607.688 & 347 \\
\hline SD & 26.35 & 20.41 \\
\hline Observations & 8 & 6 \\
\hline t Stat & \multicolumn{2}{|c|}{} \\
\hline NS : Non-significant & \multicolumn{2}{|l}{} \\
\hline
\end{tabular}

Analysis: There is no significant difference in the attitude of male tribal \& non- tribal student teachers of social science stream towards teaching profession.

\section{DISCUSSION}

Studies reviewed on attitude towards teaching profession reveal that attitude towards teaching profession are a significant predictor of teaching efficiency. Some studies indicate that female teachers possess a high degree of attitude than male teachers and teachers with positive attitudes tend to encourage their students.

The analysis of data of present study depicts that attitude towards teaching profession of non-tribal (male \& female) student teachers of Science as well as Social science stream do not show significant difference (Table: 1\&2). However studies conducted by Rawat and Sreevastava (1984) found Significant difference between male and female teacher trainees' attitude towards teaching profession. While Balan (1996) reported no significant gender difference in the attitude towards teaching of student teachers.

Naik and Pathy (1997) reiterated that female science teachers have more positive attitude towards teaching than male counterparts. Poozhikuth (1989) also stressed that female teachers have more favorable attitude towards teaching than male teachers. Ghosh and Bairagya (2010) in their study concluded that female secondary teachers possess more favorable attitudes towards teaching profession than male teachers. Benjamin et al. (2011) also supported this view that female student teachers had more favorable attitude towards teaching profession than male student teachers.

The study undertaken also depicts that in tribal category significant difference at $\mathbf{5 \%}$ level is observed between male and female student teachers of science and social science stream. Females possess more favorable attitude in comparison to Male tribal students in both the academic streams (Table: 3 \& 4). While comparison of Non-tribal (female) and Tribal (Female) students of science stream shows that tribal (female) have more favorable attitude towards teaching profession(Table: 5), while no significant difference in attitude towards profession was observed among Tribal and Non-tribal (Male) students of science stream (Table: 6 ). Table: 7 show that female student teachers of social science stream (Tribal \& Non-tribal) show no significant difference in their attitude towards teaching profession. Same is the case with male student teachers(Tribal \& Nontribal) of social science (Table: 8 ). 
Theresal and Benjamin (2011) also found that male student-teachers and femalestudents teachers have no significant difference in their attitude towards teaching profession as well as self esteem.Most of the researches and present study conclude that student teachers (female) possess more favourable attitude towards teaching than their male counterparts.Difference in attitude towards teaching profession is observed between male \& female (Tribal) student teachers of Science stream, social science stream and Tribal \& Non- tribal (female) student teachers of science stream.

In all the three groups, Tribal (female) student teachers show favourable attitude towards teaching profession.

Hence hypotheses (iii), (iv) and (v) get rejected as difference in attitude towards teaching profession is found in tribal (male \& female) student teachers of science stream and social science stream. Difference of attitude towards profession is also significant in female student teachers (Tribal \& Nontribal) of science group.

Hypotheses i, ii, vi, vii, viii, ix are accepted as no difference of attitude towards teaching profession was observed in nontribal(male \& female) student teachers of science and social science stream; Male (Tribal \& nontribal) student teachers of science stream; Female (Tribal \&nontribal) student teachers of social science stream; Male(Tribal, Nontribal) student teachers of social science stream.

\section{CONCLUSION}

Attitude being a dynamic entity gets influenced by variables like age, previous experience, beliefs, gender and stream of education. New teachers enter the teacher training program me with already established beliefs but Pre-service teacher training programmers help in shaping the attitude of teacher trainees by providing a series of experiences incorporated in their curriculum.

Srivastava (1989) opined that favourable attitude of student teachers are formed at the end of teacher training programme. Yadav (1992) revealed that training had a significant influence on their self-concept, social maturity and attitude towards teaching profession.

A positive attitude towards teaching profession can bring the desired quality in the education sector by developing sense of duty, professional competence and by giving them an insight of the student's needs and problems. This area can be further explored by the researchers.

\section{BIODATA and CONTACT ADDRESSES of the AUTHORS}

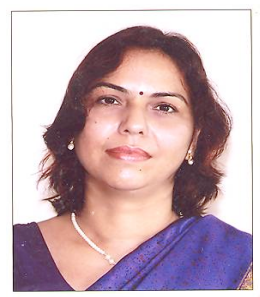

Anupama BHARgAVA is working as Asst. Professor in St. Xavier's College, Ranchi (Jharkhand), India where she teaches Educational Management and Assessment \& Evaluation to undergraduate students of education for the last 8 years. Her areas of interest are Teacher education, Distance education and Educational administration \& Management. Her papers have been published in National and International journals 
Asst. ProfessorAnupama BHARGAVA

St. Xavier's College, Ranchi, Jharkhand, INDIA

Email: anupama1229@yahoo.co.in

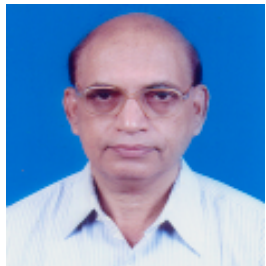

Dr. Minaketan PATHY, a former Principal in Dr. P.M. Institute of Advanced Study in Education, Sambalpur in Orissa state of India holds Master Degree in Education from Utkal University, a Ph.D. in Education from Sambalpur. He was also the sitting Dean, Faculty of Education, Sambalpur University and empanelled as an assessor for Teacher Education by NAAC, India. Dr. Pathy has about 32years of experience in teaching pedagogy in different Teacher Education Institutes of Orissa with research interest in Secondary Education, Teacher Education, and Language Teaching. He has so far produced 08 Ph.Ds. with 06 more working for Ph.D. He has published 19 papers in National and International Journals.

Former Principal, Dr. MK PATHY

Dr. P.M. Institute of Advanced Study in Education, Sambalpur, Orissa, INDIA

Email: minaketanpathy@gmail.com

\section{REFERENCES}

Anastasi C. (1957). Attitude of in-service and preservice primary school teachers journal of education psychology.

Balan, K. (1996). Attitude towards teaching profession and self concept of student teachers of Kerala. Unpublished M.Ed. dissertation, University of Calicut 36, 3,1-5, July.

Barros \& Elia. (2008). http;//www.physics .ohio -state .edu/-jossem/ICPE/D2.htmI

Benjamin, A. E. W.; Sahayarani, J. \& Stanly, L. S. (2011). A study on attitude towards teaching profession and achievement in teaching competency of B.Ed. trainees. New Frontiers in Education, 44(3), 250-253.

Bozdogan, A. E. Aydin D. \& Yildirim, K. (2007). Teachers'attitudes towards teaching profession. Kirsehir, j. Educ.8(2);83-97

Capa, Y. \& Cil, N. (2000). Teachers' Attitudes towards teaching profession An investigation of different variables. Hacettepe University J. Educ.., 18;69-73.

Cornelius, (2000). Teacher competence associated with intelligence, attitude towards teaching profession and academic achievement of teacher trainees. Unpublished M.Phil Thesis, University of Kerala.

Celikoz, N. \& Cetin, F. (2004). Anatolian teacher high school students' attitudes about the factos affecting the teaching profession. National Educ.J.,(162).

Devi, Usha, V. K. (2005). A study of role conflict, job satisfaction and select presage variables discriminating between successful and less successful Review 118 secondary school women teachers of Kerala. Unpublished PhD, University of Calicut. 
Feldman, A. (2002).Existential approaches to action research. Educational Action Reserch, 10 (2), 233-251.

Ghosh, S. and Bairgya, S. (2010). Attitude of secondary school teachers towards teaching profession in relation to some demographic variables, Edusearch 1(1), 55-58.

Gnanaguru, S. A. \& Kumar, S. (2007). Attitude of under normal and overachievers towards teaching profession and their home environment. Journal of All India Association for Educational Research, 19 (3 \& 4) 36-37.

Lily, Pushpam, A. M. (2003). Attitude towards teaching profession and job satisfaction of women teachers in Coimbatore. Journal of Ed

Mathai, M. (1992). Some presage variables discriminating between successful and less successful secondary school science teachers of Kerala. Unpublished M.Phil, University of Calicut.

McKeachie W. J. (1994). Teaching Tips; Strategies, Research, and Theory for college and University Teachers (9th eds.), Lexington, mass; D. C. Health and Company.

Mordi, C. (1991). Factors Associated with pupil's Attitudes Towards Science in Nigerian Primary Schools. Res. Sci.Technol Educ.,9 (1); 39-41.

Naik, A. K. \& Pathy, M. K. (1997). A study of the attitudes of secondary school science teachers towards teaching of science, School Science, 35 (2), 59-62.

Osunde, A. U. \& Izevbigie, T. I. (2006). An assessment of teachers' attitude towards teaching profession in Midwestern Nigeria, Education, 126 (3), 462-467.

Poozhikuth, M. (1989). Attitude towards teaching profession of college teachers, Unpuhlished M.Ed dissertation, University of Calicut.

Rawat \& Sreevastava, R. K. (1984). Attitude of male and female teacher trainees towards teaching-a comparative study. Asian journal of Psychology and Education, 13, 54-58.

Schibeci, RA. \& Riley, JP. (1986). Influence of students' background and perception on science Attitudes and Achievement. J. Res.Sci. Teach., 23(3); 177-187.

Srivastava, M. B. (1989). The impact of the teacher education programme of Lucknow university on pupil-teachers' attitude and teaching efficiency, Ph.D., University of Lucknow.

Suja, K. (2007). Interaction effect of attitude towards teaching, interest in teaching and teaching experience of job commitment of primary school teachers. M.Ed Thesis. University of Calicut.

Theresal, L. K. \& Benjamin, A. E. W. (2011). Attitude towards teaching profession and self esteem among student-teachers, New Frontiers in Education, 44 (3), 257-260.

Yadav, R. (1992). Impact of teacher training on certain personality characteristics of B.Ed. trainees, Unpublished Ph.D. Thesis, Agra : Agra University. 